\title{
Schools without measurements: towards a pedagogy of recognition
}

\author{
José Beltrán Llavador
}

\begin{abstract}
Since the OECD launched the Program for International Student Assessment (PISA) in 2000, education measurements have mainly been concerned with recording and issuing results in terms of school success or failure based on items aimed at measuring academic achievement. A major consequence of this obsession with quantifiable results, which stems from a sort of statistical monoculture, has been a shift of our attention away from the seminal fact that, indeed, educational disparities are directly linked to social inequalities. Besides, the application of accountability criteria within systems of education tends to hide the increasing deregulation of the former. Contrary to its seeming appearance, the school institution lacks clearly drawn goals and measurements. This is why, even certainly helped by rating scales but also far beyond them, we need to rethink education in terms of social justice and turn our attention from equal opportunities towards equal positions. From this analytic framework, a critical reinterpretation of the schooling process is suggested in order to approach it with the perspective of an educational policy of recognition that seeks a reconstruction of citizenship.
\end{abstract}

Keywords:

social inequalities; equal opportunities; equal positions; recognition; social justice 


\section{La escuela sin medida: hacia una pedagogía del reconocimiento}

Resumen: Desde que la OCDE puso en marcha el programa internacional para la evaluación de los estudiantes (PISA) en el año 2000, la medida de la educación se ha centrado principalmente en el registro y en la fabricación de resultados en términos de tasas de éxito y fracaso escolar, a partir de indicadores de rendimiento académico. Esta obsesión por los resultados, a partir de una especie de monocultivo estadístico, ha provocado que se desvíe la atención de un hecho central: la desigualdad educativa está directamente relacionada con la desigualdad social. Además, la aplicación de criterios de accountabilty en el sistema educativo oculta su creciente desregulación. En contra de toda apariencia, nuestra escuela no tiene ni una medida clara ni unos fines delimitados. Por ello, con ayuda de los números, pero más allá de estos, es necesario repensar la educación en términos justicia social, desplazando el foco de atención desde la igualdad de oportunidades hacia la igualdad de posiciones. A partir de este marco analítico, sugerimos una reinterpretación crítica de la escuela en clave de política educativa del reconocimiento para la reconstrucción de ciudadanía.

Palabras clave: desigualdad social; igualdad de oportunidades; igualdad de posiciones; reconocimiento; justicia social

\section{Escolas sem medições: rumo a uma pedagogia do reconhecimento}

Resumo: Desde que a OCDE pôs em marcha o Programa Internacional de Avaliação dos Estudantes (PISA), em 2000, a medida em educação centrou-se principalmente no registo e na fabricação de resultados em termos de taxas de êxito e de insucesso escolar, a partir de rendimento academic. Esta obsess pelos resultados, a partir de uma espécie de monoculture estatistica, provocou o desvio de atenção de um fato central: a desigualdade educative está diretamente relacionada com a desigualdade social. Para além disso, a aplicação de critérios de accountability no sistema educativo oculta a sua crescent desregulação. Contra toda a aparência, a nossa escolar não tem uma medida clara nem uns fins delimitados. Por isso, com a ajuda dos numerous, mas para além deles, torna-se necessário repensar a educação em termos de justiça social, deslocando o foco de atenção da igualdade de oportunidade para a igualdade de posições. A partir deste marco analítico, sugere-se uma reinterpretação crítica da escolar tendo como centro uma política educativa do reconhecimento para a reconstrução da cidadania. Palavras-chave: desigualdade social; igualdade de oportunidades; igualdade de posições; reconhecimento; justiça social

\section{Écoles sans mesures: vers une pédagogie de la reconnaissance}

Résumé: Depuis que l'OCDE a mis en place le programme international d'évaluation d'étudiants (PISA) à l'année 2000, la mesure de l'éducation a été principalement axée sur l'enregistrement et la production de résultats en termes de taux de succès et d'échec scolaires, basés sur des indicateurs de réussite académique. Cette obsession des résultats, à partir d'une sorte de monoculture statistique, a dévié l'attention d'un fait central: l'inégalité éducative est directement liée à l'inégalité sociale. En outre, l'application de critères de responsabilité dans le système d'éducation cache sa dérégulation croissante. Contre toute apparence, notre école n'a aucune mesure claire, même pas des buts delimités. Par conséquent, avec l'aide des chiffres, mais au-delà de celles-ci, il est nécessaire de repenser l'éducation en termes de justice sociale, en déplaçant le régard de l'égalité des chances vers l'égalité des positions. À partir de ce cadre d'analyse, nous suggérons une réinterprétation critique de l'école en clé de politique éducative de la reconnaissance pour la reconstruction de la citoyenneté.

Mots-clés: inégalité sociale; égalité des chances; égalité de positions; reconnaissance; justice sociale 


\begin{abstract}
"The question is knowing," objected Alice "whether you can make the words mean so many different things.

"The question is knowing," declared Humpty Dumpty, "who's in charge here... them or me!" - Lewis Carroll, Alice Through the Looking Glass
\end{abstract}

"But in Utopia, as there are no private interests, all patrimony becomes a public interest so that everybody benefits".

- Thomas More, Utopia

\title{
Introduction
}

This contribution continues a line of thought which started in 2008, in the framework of a research project under the auspices of the Ibero American Network of Research into Educational Policies ${ }^{1}$. In a meeting held in the University of Barcelona I presented, as a working document, a paper entitled "Alternative indicators or alternatives to the indicators? Some reflections on educational policies" ["¿Indicadores alternativos o alternativa a los indicadores? Algunas reflexiones sobre políticas educativas"] (Beltrán \& Villar, 2010; Beltrán, 2012).²

The question I then posed, in the form of an exploratory hypothesis, was the following; How far might the aspiration of developing alternative indicators for education end up, although unintentionally, legitimating and justifying the currently predominant frame of reference which over several decades has been used to measure the state of education at an international level? In other words; should we just offer other, better indicators of educational quality? Or could we not perhaps change our outlook, move our frames of reference, our most common frames of meaning, and propose alternatives to the dominant notion of "indicators" itself?

These questions tried to return to the point at which the possibility of constructing a kind of universal system of indicators was proposed. At that time, even within in the heart of the OECD itself, philosophical doubts there arose about the relevance of this instrument. Despite not a little resistance, these doubts gradually gave way to growing persuasions of a statistical nature, which gave rise to the implantation of the arithmetic policy which we know today, an all-powerful internationally disseminated indicators industry, which exerts its influence over developed countries and those in process of development. The influence exerted by the system of indicators has been converted in doctrine, so that what started out as a descriptive informative instrument, is now interpreted as being normative. 
In that initial document, I warned that the task of constructing alternative indicators, or if you will, counter indicators, is certainly a noble one, but probably would not be as effective as one might wish, or perhaps it would merely reinforce and legitimize the same machinery it wishes to question, as it is difficult to put together a construction of the magnitude of that which one aims to fight against. I also observed therein, backed up by the analysis of Raymond Williams of the notion of production mode, which is similar to this notion, that the same concept of indicator is, in many important points, a prisoner of the same social orders which it bids to analyze. In effect, the use or application of the indicators to measure education winds up incurring in a kind of circularity. Really, it offers no advances in the field of instrumental information, but brings us back to the starting point: the confirmation of inequalities in performance, but with no explanation of the causes of these inequalities nor the elements required to improve them; but rather the installation of a system of classification or ranking, which supposes a qualification (positive sanction) or disqualification (negative sanction) depending on the results obtained. Thus, I suggested in a hypothetical mode the possibility of beginning to think not so much, or not only, about the construction of "alternative indicators", but more about an alternative to these indicators.

A second reflection, two years later, takes up this question at the point at which it had been formulated. On this occasion, the title was "Places of equity: Towards a topographical reason" ["Los lugares de la equidad: hacia una razón topográfica"] (Beltrán, 2010). There, I examined the context of the notion of "equity" in two separate educational reports. Each of them corresponded to a different macro-organism at an international scale (OECD and EU) which, although not of an educational nature, include educational goals and interests. Both reports were framed in what I called distinct epistemic regions, and served as pretexts, to address some considerations of a general character, on the complexity of measuring or comparing education and on the use of the term "equity". In that sense, the article aimed not so much to "resolve" the disjunctive raised, but rather to "dissolve" it, suggesting an approach that aimed to be critical, integrative and complementary. It was about re-contextualizing the systems of indicators in areas of wider understanding, a task which allows us to advance in the analysis of educational reality without abstractions, of those historical (temporal) and geographical (spatial) coordinates of which we are built as social subjects, which explain us and to which we try to give an explanation. In short, I aimed to take steps in pursuit of a geography of knowledge, which could combine temporal reason with topographical reason, whilst at the same time integrating arithmetical reason. What I proposed was to bring the numerical indicators into line by submitting them to a test of their contextualization by considering variables of a social and economic nature, with the help of the systems of geographical information. 
The third contribution, entitled "The forward-looking school: the task ahead" ["La escuela anticipada: la tarea por hacer"] (Beltrán, 2015), picked up the previous reflections diverting the attention or the focus from the indicators to the models. Here, I suggested considering a model of analysis of the school, which was not only descriptive (post-facto), but propositional (ante-facto). The starting point was to try to invert the consideration of the school as an object and start to think of it as a subject. Subject to change and subject to analysis, in a process of characteristic reflexivity of our societies of growing complexity. Following this model, the school becomes an actor which can not only explain social change but can also bring it about and become involved in it, and is thus partly responsible for it. Finally, I held that the authentic meaning of a forward-looking school is an institution that can foresee some of the effects that it may have both individual and social on those it educates and which takes upon itself and promotes its transforming role.

In what follows, I aim to continue from the progression initiated in the previous texts towards what I can now begin to consider as a "pragmatic turn: this turn consists, as I will try to explain, in that the successive frameworks of understanding can act at the same time as frameworks for action. These frameworks emphasize the creativity of an action and the value of a conversation, concepts that I will define later. Defending that what is relevant is not the mono-logical imposition (culture in a regime of monopoly or imposition) of a single point of view elaborated by a factory of indicators at the service of human capital, but the dialogical conversation (culture in a regime of cooperation) from the social space of points of view elaborated from a cooperative undertaking in pursuit of the common good. In order to do that, on this occasion I will take as a point of reference the case of PISA (the Program for International Student Assessment), developed by the education section of the OECD.

\section{Overmeasured education}

The initial idea is that, although it appears to do contrary, PISA promises more than it gives, and in return offers other things which it says it does not deal with. However, its influence on the international educational agenda is exaggerated, it is excessive for the results it generates. It aims to be a useful instrument for the school and the teachers, but it lacks value in this sense. We shall follow Julio Carabaña (2015) in his welltempered criticism of the PISA report. Carabaña begins by recognizing that "PISA is an admirable undertaking for the width of its approach, the rigor of its execution, the depth of its reports and the generosity of its diffusion" (Carabaña, 2015: 18). From its inauguration in 2000, PISA has had an enormous repercussion in the media, amply exceeding that of its predecessors. A large part of this success is due to the format in which the 
results are published, in the form of a worldwide classification or ranking which places countries from the highest to the lowest positions, implying that the countries which occupy the highest places should serve as models for the others.

However, "unfortunately, this huge undertaking which is PISA has a failing already seen of old in massive evaluations: its tests measure competencies that depend on the whole life experience of the students, not the knowledge they acquire in the schools. As the OECD warns and its own analyses show, the competences that the PISA tests measure depend little if at all on the schools. Furthermore (...) they do not even depend on the pedagogical and political changes that PISA proposes." It is this failing, in the opinion of Carabaña, which invalidates PISA in its objective to contribute to the improvement of schools and educational systems. It is true that PISA gives us a lot of information, but no that which proves useful for guiding reforms and improvements. But "we are not talking about a minor or accidental failing, but a fundamental one, which turns PISA first into a failure, and, with the passing of time, into a fraud." (Carabaña, 2015: 20). PISA describes well certain aspects relating to educational systems, homes, the social structures of the countries which participate, but does not explain what they announce, namely how schools can influence students' school results.

What PISA really does is to attribute to the school an influence which goes beyond the school, and eventually ends up blaming the educational system for things which, strictly speaking, are not their concern. That which endows PISA with its singular character, if we go by the OECD presentation on their web page is as follows: "PISA is unique because it develops tests which are not directly connected to the school curriculum. The tests are designed to evaluate the degree to which students that finish compulsory education can apply their knowledge to real life situations and are equipped for a full participation in society." The PISA project "focuses on what young people are going to a need in their future life and its aim is to evaluate what they will be able to do thanks to what they have learned." This is what PISA calls literacy, the ability to apply knowledge in real life." (OECD, 2001: 14). Presented in this way, one might think that PISA has the intention of being a prospective study, but the report says nothing about the challenges the school must face in the coming decades, except for general references to globalization and the society of knowledge.

"The position of PISA is that, if we aim to educate for life, schools should put aside detailed information and dedicate themselves on teaching the general concepts and skills on which depends (or which constitute literacy)." (Carabaña, 2015: 63). Thus, "the direct evaluation of knowledge and skills at the end of the period of basic education allows the OECD/PISA project to examine the degree of preparation of young people for their lives as adults and, to a degree, analyze the effectiveness of educational systems. The aim of the project is to evaluate the performance of educational systems relative to their underlying objectives (as defined by society) and not relative to the teaching and 
learning of a corpus of knowledge. The measurement of authentic results is necessary if we aim to encourage the centers of learning and the educational systems to concentrate on current challenges" (OECD, 2000: 24).

To put it another way, if they devote themselves to the teaching of a body of knowledge, present-day schools disobey the imperative of the society (of knowledge?) to educate in literacy. So, PISA will encourage schools "to concentrate on their true objectives, the preparation for life, not, as now, the storage of useless information." Carabaña warns of the "importance of the concept of literacy and the educational ideology which fuels it", which invites us "to ask ourselves for the source of these ideas in PISA. In particular, from where does PISA get its knowledge about what is important in life (and what society wants), about its rivalry, opposition to, or incompatibility with 'curricular' information and about what actually happens in existing schools." (Carabaña, 2015: 63).

These are, without doubt, important questions because "PISA seems to know that what is important for life, especially for the future, is not to have information, but to know how to use it thanks to the economists who study human capital" which, as he adds in a footnote, "seems to include the idea that 'before' people were paid for what they knew, not for what they knew how to do, as will end up happening in the future." (Carabaña, 2015: 63-64).

Carabaña observes that perhaps one of the keys to the success of PISA is in its integration of the two most powerful ideological currents in educational matters, the economic utilization of human capital and pedagogical progressivism the apparent common denominator of which is the assumption that schools should give less importance to content and more to procedures and general competencies.

Based on measuring general competencies (of the world of life), what the school offers (curricular content or school knowledge) remains excessive, which is the same as saying, remains undervalued. And this fact is in no way either trivial or neutral, as we shall see below. In this sense, before moving on to the next section, it may be useful to reread this passage: "the theme of measurement, (that is, of the quantified rationality of appraisal) becomes crucial again. However, it only becomes crucial in a paradoxical way, because all the measures that capitalism wants to organize, and, at the same time, control, are currently unpalatable" (Negri, 2008: 55).

\section{The measurement of learning}

In his essay about PISA, Carabaña cautions that both this report and its predecessors set out from an assumption which needs to be checked over: the idea that reading and calculation should be treated as being equals and the fact of problem solving. "There is no doubt," he points out, "that what are traditionally called the four rules 
are the responsibility of the schools, they distinguish perfectly between intelligence, attitudes and character qualities and are particularly important in modern societies. But they do not determine the rank of job opportunities and social participation at any more than a very basic level: they differentiate between the literate and the illiterate, but scarcely distinguish between them. Reading more or less quickly, having better or worse handwriting, calculating more or less easily or precisely are not qualities that carry much weight in being successful as a business person or an artist, nor are they criteria to discriminate between two candidates for a job as an office worker, without mentioning a job as a manual worker or an executive" (Carabaña, 2015: 25-26).

But as well as the so-called "four rules" of arithmetic, which are specifically a task of the school, problem solving is learned beyond school, and is related to intelligence and attitude. As Carabaña points out in an aside which for the purposes of this reflection is important, as we shall see, the philosophical school of pragmatism conceives intelligence to be precisely the ability to solve problems. There is a fundamental difference between the concept of learning in terms of reading and writing and calculation and its definition in terms of problem solving. "First of all are the basic universal objectives of primary schools, which cannot be used to measure equality of opportunities. Problem solving, however, is important for obtaining equality of opportunities in life, but it does not particularly depend on the schools. None of them complies with the double condition of depending on the schools and being important to fight inequality, but they are precisely the ones which the EEOS [Equality of Educational Opportunity Survey, better known as the Coleman report published in 1964] chose to measure" (Carabaña, 2015: 27).

This EEOS, which precedes the PISA report that incurs in the same confusion between the measurement of specific aspects (learning) and general aspects (aptitude), did not find major differences in learning between schools, differences moreover that were not due to the resources available in the centers, but to their social composition. On examining the tests used in the EEOS, Christopher Jencks formulated the hypothesis that the reason is because the tests do not measure learning, but aptitudes. "And as in the analysis it turns out that the tests of aptitude differ more between schools than those of performance, the EEOR [Equality of Educational Opportunity Report] adopts them as a criterion of the effects of the schools." The consequence which is obtained from this is important, because it is repeated in the format of the PISA report: "The EEOR seems to have passed from trying to measure what it wanted to investigate, to investigating what it could measure best. The investigation moves from aptitudes to the school factors which determine them. Implicitly, aptitudes are converted into the objective of the schools. The contents and skills specific to the schools are put to one side; problem solving probably becomes included among the general aptitudes" (Carabaña, 2015: 37-38). 
In the conclusions of his study, Carabaña synthesizes the operation of deconstruction or decoding he has carried out with respect to the value of PISA for schools and teachers. From one report to the next, he observes, PISA has been distilling a series of recommendations for schools finally leaving just the few which showed a strong relationship with literacy: among the most substantial, discipline in the classroom and the repetition of a school year stand out. Even though, as he pointed out, it falls into a confusion between the causes and effects of literacy. "In a way, it appears pathetic that in its quandary PISA has come to insinuate that students do not repeat a school year because of their bad results, but that they have bad results because they have to repeat" (Carabaña, 2015: 212).

In general, continues Carabaña, "what all the strong associations with literacy that PISA discovers have in common is that they are more easily understandable if, inverting the causal order that PISA supposes, we put literacy at the beginning. So that, "when literacy appears to be more associated with singing in a choir than with study time, PISA explains that literacy and musical hobbies go together because of the cultural level of the parents." So that "whoever checks closely its discourses and its figures, notices that PISA does not accredit literacy with more associations than those produced by itself."

Yet, this would not be so serious if PISA would lower its pretensions and recognize its value as a report which, although questionable in its methods, throws up data which can well be of interest for educational research. But PISA goes beyond that, and considers that its work gives it an obligation to emit recommendations. And this is where PISA shows its excess of ambition, its lack of moderation, its excessive aspirations for a school thought out in an excessive way. How do we qualify Carabaña asks himself, "the distance which sometimes exists between the data and analysis which it supplies and the words with which they are interpreted and presented?" (Carabaña, 2015: 213).

Despite an explicit declaration in the recent 2012 report that "this volume does not contain political prescriptions", after recognizing that "although their causal nature cannot be established, it is possible to extract an extensive network of correlations between some of the dimensions of student performance and a wide range of factors that can conceivably affect it" (OECD, 2013, IV: 190), PISA dictates political prescriptions. Recognizing that it cannot establish causal relationships, PISA recommends ensuring that students learn in a positive climate of discipline. And the formula for that is by attracting talented teachers, although "the nature of this relationship cannot be discerned from the data" (OECD, 2013, IV: 190). It doesn't matter that there is no correlation between the data, it doesn't matter that there are no empirical proofs or solid arguments which allow us to establish these relationships. It is all about the fact that "both governments and corporations should know what is required to construct an effective workforce: a fund of talented people from which to recruit new workers; a clean and 
rigorous recruitment process; initial and continuous training; adequate compensation; rewards for the best, help for those who need to improve and means of persuading those who cannot or do not improve to leave the profession." (OECD, 2013, IV: 191). Here, the order of discourse has given way to the discourse of order.

\section{The uncertainty principle: from indicators to models}

In a metaphorical mode, we remember that the uncertainty principle of the quantum physicist Heisenberg which says that the instrument of observation alters what is being observed. To put it very succinctly, Heisenberg maintains that the simple fact of applying any beam of light to a particle to observe its speed and amount of movement causes the beam of light to rebound against the particle and modify the values observed, so that the values in conditions of "darkness" which we cannot see differ from those taken when we apply the light in order to observe them. That is, there will always be a zone of indetermination, since we can never know with absolute precision the amount of movement and the speed of the particle due to external agents.

Starting from this simile, the previous summarily critical presentation of PISA allows us to extract a series of reflections. PISA, effectively, is a powerful instrument of observation, but in good measure it is tailor made to make us see what it wants us to see. Plain language, and the informal knowledge which comes with accumulated experience, translates the quantum physicist's principle as "everything depends on the color of the glass through which one looks at it." In the case of PISA, although wanting to be propositional, it ends up being prescriptive. Although aiming to have general validity, it ends up defending selective criteria. Apparently assuming the principle of equal opportunity, it ends up legitimizing the inequality of positions: far from questioning this inequality, it naturalizes it by accepting it as an initial assumption, thereby incurring in a petitio principii: it adopts as a premise the same thing it says in its conclusion, it constructs a demostration supported by the conclusion it wishes to reach. PISA starts from the premise that there are unequal academic results and PISA concludes that there are unequal academic results. So, what new information does it offer? PISA offers, as it claims, a "singular" glance towards the school and the educational systems. It doesn't matter much, if at all, what one measures or tries to measure, but how it is measured, since here the medium (the measurment) is the message.

Recently, the economists Joseph E. Stiglitz, Amartya Sen and Jean-Paul Fitoussi (2013) have tried to go beyond the GDP as an indicator of progress in our lifes as far as possible. In the chapter dedicated to the quality of life, after paying attention to health, they pause to analyze the value of education, and begin with an interesting observation: "education is important for the quality of life whatever its effects on people's earnings and productivity" (Stiglitz, Sen \& Fitoussi: 2013: 125). Their conclusion is no less 
pertinent: "Regarding other components of the quality of life, the main problem for the indicators in this area is not the lack of detailled information about education itself, but the lack of surveys which measure education as well as other aspects of the individual quality of life." (Stiglitz, Sen \& Fitoussi: 2013: 127). In recommendation number 2 they point out that, when measuring all these characteristics, both objective and subjective data are required. Effectively, they are calling for the return of the subject or, what amounts to the same thing, that subjects should no longer be considered as objects.

\section{A pragmatic turn}

It is no accident that Carabaña's criticism of the PISA report alluded to the current of pragmatism. While the term is impregnated with a certain ambiguity because it refers to both a specific line of reflection and an attitude or perspective of the world, for the purpose of this reflection we shall choose one of the most notable representatives who focused his attention on the area of education: John Dewey.

John Dewey is recognized as being one of the principal drivers behind and diffusors of pragmatic thinking, together with Charles S. Peirce and William James. Precisely the last of these in the preface to his 1907 work Pragmatism (2007) declares himself indebted to Dewey who, for him, represented the basis of pragmatic theory. In Dewey's long life bridging two centuries and in an era of social, cultural and political changes, both significant and profound, the notion of pragmatism supposed a crystallization and a systematic explanation for some of those changes that were inevitably to reposition the western world in general before a new horizon.

Without doubt, Dewey was a witness and a privileged actor in a country, the United States, that played a major role in the huge advance towards schooling for the masses. However, Dewey realized that more (school) was not necessarily a guarantee of better (citizens), and that the sign of quantity did not correspond to the sign of quality. For Dewey, this reflection supposed for Dewey the confirmation of a new separation, this time between technical progress and economic development on the one hand, and awareness or moral advancement, on the other. Overcoming this division would only be possible by means of an educational culture of democracy, that allowed the full and conscious participation of the social actors in the construction of a democratic society. Overcoming that excision consists in regaining the experience of continuity, organic unity and a sense of community.

In the framework of pragmatic theories, Dewey supports the need to consider thought as a natural process. The logical processes, correspond to the vital activities that involve doubt and investigation. Dewey affirms that experimental research is of a practical nature, and that the artificial separation of thought and action is as erroneous as it is dangerous. These ideas, a constant struggle against dualism and the large 
division that has characterized a large part of the history of western thought, will become a recurrent theme in the reflection of Dewey regarding education and the defense of democracy. So, for example, as far as education is concerned, his endeavor in overcoming the differences between the culture of the intellectual elite and the "technicalprofessional" culture of the popular masses is notable. On the other hand, in the field of politics and moral reflection, one of his most persistent arguments is the need not to separate ends and means, achievements and values. Both concerns, of a political and educational character, form part of the same project and will be reflected throughout his prolific work, and constitute a continuum of his philosophical interests and an example of coherence when it comes to overcoming the essentialist dichotomies between theory and practice, speculation and action, thought and public compromise.

Conscious of forming part of a line of thought which sought to revise and reconstruct a long tradition of which they felt themselves to be heirs, "the old-guard pragmatists had said things such as that the function of the mind is not to mirror passively the order of the universe, but to ingeniously come to terms with things, understanding 'thing' in the common meaning of the word (precisely the one the Greeks gave to prágmata: affairs in hand, problems, tasks, plans). They also affirmed that abstract ideas are significant if they are translated into actions, and that science is a fallible venture, both experimental and creative." So, everything, which could be associated with a theory of pragmatist knowledge, could be accompanied by a theory of pragmatist policy, which would insist that "democracy does not only consist of debating and reaching agreements, but in doing those things under certain conditions, in a certain climate of dialogue and with certain provisions learnt, or that politics is not possible without education and education is not possible without politics (dialectics?) or that social problems need a type of research that does not depend solely on experts" (Del Castillo, 2015: 15-16).

\section{For a pedagogy of recognition}

So then, what do we understand by research? To what kind of investigation do the pragmatists and Dewey refer, bearing in mind that in a certain way, and in our case, the Program for International Student Assessment and other similar projects, entail at the same time a certain program of research which starts with an empirical field study?

For Dewey, to investigate means to question. Thus, what makes a situation investigable is its being uncertain, or questionable; a quality which is, in turn, a singular specific uncertainty. A situation becomes problematical in the process itself of being investigated, but at the same time, posing a problem makes no sense unless the terms of the approach point towards a possible solution. Both facts and ideas are operational, and can cooperate between themselves. Ideas are operational because they 
offer proposals, action plans for existing conditions, with the aim of obtaining selected, completely coherent new facts. And facts are operational because they are not merely the results of observation, they are not final or complete in themselves, nor can they be sharply distinguished from the ideas, from the hypotheses. Rather, there is a constant interrelationship between facts and ideas.

For Dewey, a successful investigation, after all, is one that ends in "a belief" or "knowledge". To refer to this, he uses the expression "guaranteed assertion", specifying the end of a situation in which the reasons the investigation was started have been suppressed. "So, it is the process of investigation itself that guarantees the assertion. "And", adds Dewey, "the use of a term that expresses potentiality rather than actuality is not innocent: it involves the acknowledgement (the italics are mine) that all the special conclusions of special investigations are parts of a unique undertaking which is in a state of continual renewal." (Pérez de Tudela, 1988: 195).

This common scheme of investigation, this model (pattern) of an innumerable variety of investigations, would put an end to the intimate dualisms that divide human beings, reestablishing the continuity of each of its spheres de action, and furnishing frameworks of action. "In other words, putting an end to the wrongs produced by the secular split between theory and practice, ends and means, knowledge and action." This goal entails, for Dewey, the acceptance of three fundamental hypotheses:

1. The traditional distinction between "theoretical judgements" and "practical judgements" has absolutely no sense. All judgements respond to the same characteristics, because of the simple fact that knowledge is evaluation.

2. There is a very close intrinsic relationship between "philosophy" and "education". We could even define philosophy as "the general theory of education".

3. There is also a close correlation between the moral reconstruction (...), the re-construction of educational institutions and democracy. Because being a democrat, for Dewey, is no more than believing in the universal function of science (Pérez de Tudela, 1988: 196).

If the result of the action is the truth or falsity of the judgement, then, each scientificdescriptive affirmation implies, directly or indirectly, "things that need to be done", possibilities to be implemented. The pragmatic turn in education takes us from dogmatic prescription, (What does PISA offer to education? More discipline in the service of human capital? Know-how, at the expense of knowledge?) to contingency, towards the possibilities of human creation, intervention and participation. 
"The most important of the dualisms that overwhelm Humanity today, the separation between material, mechanical and scientific things, on the one hand, and morals and ideals on the other, will end when science becomes fully impregnated with a sense of conscious human value. While ends are not considered to be individual answers to concrete needs and opportunities, the mind will be satisfied by abstractions, and the stimulus para make use of the natural sciences and historical data in moral and social areas will be lacking" (Dewey, 1955: 237).

Thus, Dewey is suggesting that the educational process is its own end, there is no end which is superior to the process itself. And this process, at the same time, demands its continual reconstruction. In fact, Dewey is anticipating what Axel Honneth will later reformulate as "the struggle for recognition". For Honneth, "the guiding ideas, which have become abstract ideas, no longer provide a generally valid system of references by which one can measure the social value of specific qualities and capabilities, as they must always be specified by additional cultural interpretations in order to find application in this sphere of recognition. With that, the values which are recognized for diverse forms of auto-realization are calculated, but also the way in which the corresponding qualities and capacities are defined, fundamentally in interpretations, historically predominant in the establishment of social objectives." (Honneth, 1997: 155). But it is also the case that, as already pointed out by Georg Simmel, the relationships of social valuation (understanding valuation to also mean evaluation), are indirectly linked to the model de distribution of income, "the economic debates also belong constitutively to this form of struggle for recognition." In this way, "social valuation adopts a model that, with the forms of recognition with which they are bound, grants them the character of asymmetric relationships between the historical-vitally individualized subjects" (Honneth, 1997: 156). Instead, "in the conditions of modern society, solidarity is bound by it to the budget for social relations as a symmetric valuation between individualized (and autonomous) subjects; in this sense, evaluate symmetrically means be considered reciprocally in the light of the values that make the capacities and qualities of anybody else seem significant for the common praxis" (Honneth, 1997: 158). Here "symmetrical", clarifies the German thinker, does not mean evaluate in equal measure, as, "ultimately, no collective objective is representable as so quantitively fixed that it establishes an exact comparison with the value of the contribution of the individual." On the contrary, "symmetrical" means "that all subjects, without exception, have the opportunity of feeling that their own operations and capacities are valuable to society" (Honneth, 1997: 159). 


\section{Accountability, sense-ability}

In reality, PISA, like other mechanisms of indicators, starts from a fallacy or deliberate equivocation: the need for accountability, to give credit (belief or confidence, but also offer a loan) to that which supposedly needs it: the school. PISA presupposes a school without measure, without control and a school without credit, without confidence and it demands accountability, (using this language of products and of production, that is educational performance), from this educational institution to which the state confides the education of its citizens, and precisely because they are trusted, the economy (the market of human capital) distrusts the State (see, for example, Benavente \& Peixoto, 2015). Thus, it ignores the fact that a part of the self-interest may correspond to the common good or public patrimony, in an expression already used in Thomas More's Utopia five centuries ago.

There are at least two meanings for the activity of count, and they are not incompatible: enumerate and tell. Both are ways of registering reality, with different codes. In both cases, the intention is to encipher and decipher reality, code and decode it: understand it from both its mathematizable and discursive aspects. The problem is not in appealing for one kind of code or the other, but its misuse, its improper use and appropriation. One cannot compare the incomparable (What does Finland have to do with Spain or Portugal?), but one can aim to measure life (or one record of it, such as school in this case), although we plot a grid (some indicators in the form of coordinates) to limit some of its aspects, always remembering that the map is not the territory. One can aim to understand aspects of life para enrich it and learn from this understanding. A system of indicators should be taken, literally, as a system of indications, signs that suggest paths or possible itineraries. But the signs are not static categories, but rather they represent, or should represent, a dynamic set of relationships: the indices, the indicators, suggest possible directions. They do not belong to the order of need, but that of contingency. Thus, a system of indicators should not have pretentions of truth, or if you will, of objectivity, (remember that facts are interrelated with ideas), but at most pretentions of verisimilitude (of resemblance to the truth) or, if you will, of intersubjectivity (given that the facts shown are subjected to different interpretations, to different points of view). Therefore, a system of indicators should be considered as a laboratory, not as a recipe book. A system of indicators could be considered as the workshop or the office of a translator, not as the pulpit of a prophet. One problem with indicators is that, as we see in the PISA program, they present as measurable what is "unmeasurable", that is, what is "outside" quantitative measurement, and this continues to be an enormous difficulty. The difficulty of "exploiting" and calculating a relationship with knowledge (which it aims to reduce to knowhow) that goes beyond the idea of measurement itself. The difficulty of wanting to submit to "speculation", to speculative operations, 
that which corresponds to the territory of creativity of action (Joas, 2013), the job of a creative democracy (Dewey, 1998). If we admit that a program like PISA is a program of evaluation, we should not forget that to evaluate means to emit value judgements on things that matter, in effect, to use the title of Bernard Stiegler (2015), "what makes life worth living." And in this, yes, we can count life, not to trap it within a grid (with the undesired or deliberate effect of devaluing it, of depreciating it), but to give it all the value it deserves: live life to tell it and, even, through literature or poetry, live to sing it.

Furthermore, we can also pay attention to other things which are not accounts. We can pay attention to meaning, to sense. Or equally, we can give meaning, constructing and reconstructing it, in a battle to carry on with the la metaphor of Honneth, for the recognition of the contingency and for the possibility of gaining provisionally a certain amount of terrain from chance. For this, and drawing once more on the simile of the laboratory, we can look to language, and within this, to some test tube words. In general, a large part of knowledge has arisen from "test tube words". (Arnau, 2008). "Wittgenstein asked (Philosophical Investigations § 50) what length the standard meter in Paris would have. What standard could measure it? How can one stop the infinite regression? Like the meter in Paris, test tube words are the standards that permit the elaboration of certain language games which, in turn, make discursive practices (knowing) possible. The elemental particle of subatomic physics, the chess piece, the concept of identity in formal logic (...) are some examples of test tube words." (Arnau, 2008: 32). A test tube word points to the end of the explanation, but does not allow anyone to think about the explanation which it gives. "It is a term which answers well when we say: Explain! but which sneaks off when say: Explain yourself!" (Arnau, 2008: 33).

If the word "indicator" really is a test tube word, we cannot aspire to explain it, but we can aspire to find other alternatives that contribute towards to returning it to the laboratory from whence it arose to avoid it continuing to contaminate the discourses of common language and stop it being a celebrity. And partly we can hope to fulfil this aspiration if we focus on the possibility of offering meaning; that is, to use Weber's terminology for social sciences again, in the possibility of understanding (one of the forms of recognizing) and not just explaining. After all, "in the culture in which we live (...) each time it has been more common to accept the relationship between being a person and recognizing oneself through some personal story" (Del Castillo, 2015: 99). Continuing with the pragmatic turn, one of its last representatives, Richard Rorty, held that the citizens of free societies need to construct basic languages with which to "formulate" long term projects, our deepest doubts about ourselves, and our highest hopes", that is, discourses with which we "narrate", sometimes prospectively, and sometimes retrospectively, the story of our lives" (Rorty, 1991: 91). In this attempt to understand ourselves, to recognize ourselves, from a narrative and biographical learning, from a new political and epistemological grammar that considers 
the inter-subjective relationships between subjects that occupy unequal positions to procure that they attain equal positions, one can avoid the discrimination of individuals and collectives, not so much by recognizing what differences they have, but by what they have in common. Reformulating and updating the legacy initiated in the pedagogy of the oppressed, as Paulo Freire demanded for the entirety of his thinking, now is the time to reformulate and continue the task from a pedagogy of recognition. This pedagogy, based experience of the difference itself, would not place as much emphasis on describing and explaining the inequality of opportunities, but above all on understanding and overcoming the inequality of positions (Dubet, 2005). And this is only possible from the right to think freely (not just knowhow, as PISA recommends, but knowledge and knowhow) and participate in a continual open conversation that inspires us to reflection and intervention in the continual reconstruction of our society. To do this, new vocabularies will be needed, with neologisms which in turn act as keywords, capable of channeling and giving expression to different ways of representing other alternative realities. This is not impossible and there have been some precedents which have given rise to good samples of it (remember the other quotation which heads this reflection, now that we are celebrating the five hundredth anniversary of its creation), because after all, "education contains an inexhaustible thesaurus", which depends on human creativity and imagination, and which allows us to commit ourselves to reality and do things with words.

\section{Conclusion}

In synthesis, what I suggested in my first contribution to the issue of international educational evaluations was a change of perspective from the possibility of proposing alternative indicators to the need to propose an alternative to the notion of indicators itself. In my second contribution, without abandoning this previous position, I offered a new displacement in an attempt to subject or subordinate the logic (arithmetical, countable) of the indicators to different socio-logical visions (social practices), which could situate them and explain them in wider contexts. In this way, I tried to reduce the primacy or hegemony of indicators. Indicators, yes, but subjected to an exercise of epistemological and sociological vigilance, and used as mere auxiliary tools, as means and not as ends. In the third text, I proposed a new advance, from the descriptive analyses (with normative or "normalizing" effects) focused on results or the products of the indicators themselves, towards propositional models centered on processes. In the present text, I have continued this reflection, starting from a critique based on PISA, focusing on what I have called "the pragmatic turn" in education. This turn consists in the fact that successive frameworks of understanding can act at the same time as frameworks of action. These frameworks emphasize the creativity of action (in contingency) 
and the value of conversation (before the techniques of persuasion) as tools for knowledge and social transformation for democratic ends. Perhaps we should ask first not about the measure of education, but about the reason for education. Perhaps it will be then, for the task of reconstructing the reason or reasons for education, that we can adopt the timeliest, most necessary and most responsible "measures". To that end, the following steps, inevitably but also in a desirable way, will continue with the participation of new interlocutors and new dialogues in the conversation which has begun.

\section{Endnotes}

1 This paper is a work from the Erasmus + Programme of the European Union: From Tradition to Innovation in Teacher Training Institutions. Project reference number: 573685-EPP-1-2016-1-ESEPPKA2-CBHE-JP. It also forms part of the scientific activities from the Iberoamerican Network of Research in Higher Education Policies (RIAIPE). The author wishes to express his acknowledgement to the discussion of the text with the colleagues who participate in both projects. A previous and shorter version of this paper in spanish was published, with the title "School Measure and Value. From account-ability to sense-ability", in Profesorado. Revista de currículum y formación del profesorado, vol. 10 (3), 2016, 119-143. The Spanish original version was translated to English by Christopher Dennison.

2 This worry about indicators gave rise to a series of reflections published on the same Network. See, for example, Teodoro \& Montané (coord.) (2009), Teodoro \& Jezine (org.) (2012), and Beltrán \& Teodoro (coord.) (2017).

\section{References}

Afonso, A. J. (2007). Estado, políticas educacionais e obsessão avaliativa. Contrapontos, 7 (1), 11-22.

Arnau, J. (2008). Rendir el sentido. Filosofía y traducción. Valencia: Pre-Textos.

Beltrán, J. (2010). Los lugares de la equidad. Hacia una razón topográfica. Seminario Internacional de Políticas Educativas Iberoamericanas. Tendencias, desafíos y compromisos. Barcelona, may 17-18 .

Beltrán, J. \& Villar, A. (2010). Avaliação em Educação: algunas considerações respeito dos indicadores. Revista Educação \& Linguagem, 13-21, 134-149.

Beltrán, J. (2012). ¿Indicadores alternativos o alternativa a los indicadores? Algunas consideraciones de política educativa. In A. Teodoro \& E. Jezine (Orgs). Organizações Internacionais e modos de regulação das políticas de educação. Indicadores e comparações internacionais (pp. 35-64). Brasilia: Liber Livro.

Beltrán, J. (2015). La escuela anticipada, la tarea por hacer. I Conferência Ibérica de Sociologia da Educação. A educação na Europa do Sul. Constrangimentos e desafios em tempos incertos. Faculdade de Ciências Sociais e Humanas da Universidade Nova de Lisboa, juny 9-11.

Beltrán, J. \& Teodoro, A. (coord.) (2017). Presentación. Medir la educación: perspectivas desde la crítica sociológica. RASE. Revista de Sociología de la Educación, 10 (2), 110-114 [monograph on the measure of education coordinated by Beltrán and Teodoro].

Benavent, A. \& Peixoto, P. (coord.). (2015). Menos Estado Social, uma Escola Mais Desigual. Observatòrio de Políticas de Educaçao e de Formaçao: CES - UC, CelEF - ULHT.

Carabaña, J. (2015). La inutilidad de PISA para las escuelas. Madrid: Los libros de la Catarata. 
Del Castillo, R. (2015). Rorty y el giro pragmático. Madrid: Ediciones de El País.

Dewey, J. (1955). La reconstrucción de la filosofía. Buenos Aires: Aguilar.

Dewey, J. (1996). Democracia creativa: la tarea ante nosotros. In Liberalismo y otros ensayos (pp. 199205). Valencia: Edicions Alfons el Magnànim.

Dewey, J. (1998). Democracia y educación. Madrid: Morata.

Dubet, F. (2005). La escuela de las oportunidades. ¿Qué es una escuela justa? Barcelona: Gedisa.

Elliot, J. (2002). La paradoja de la reforma educativa en el Estado evaluador: consecuencias para la formación docente. Perspectivas, XXXII (3), september, 1-19.

Honneth, A. (1997). La lucha por el reconocimiento. Barcelona: Crítica.

Joas, H. (2013). La creatividad de la acción. Madrid: CIS.

Negri, A. (2008). La fábrica de porcelana. Una nueva gramática de la política. Barcelona: Paidós.

OCDE (2001). Conaissances et competénces: des atouts pour la vie. Premiers resultats de PISA 2000. Ensegnement et competences. Paris: OECD Publishing.

OCDE (2013). PISA 2012 Results: What Makes School Successful? Resources, Policies and Practices. Paris: OECD Publishing.

Pérez de Tudela, J. (1998). El pragmatismo americano: acción racional y reconstrucción de sentido. Madrid: Cincel.

Siglitz, J., Sen, A. \& Fitoussi, J-P. (2013). Medir nuestras vidas. Las limitaciones del PIB como indicador de progreso. Barcelona: RBA.

Stiegler, B. (2015). Lo que hace que la vida merezca ser vivida. De la farmacología. Avarigani editores.

Teodoro, A. \& Montané, A. (coord.) (2009). Espejo y reflejo: Políticas curriculares y evaluaciones internacionales. Alzira: Germania.

Teodoro, A. \& Jezine, E. (2012). Organizações Internacionais e modos de regulação das políticas de educação. Indicadores e comparações internacionais. Brasilia: Liber livro.

José Beltran Llavador

Departament of Sociology and Social Anthropology

from the University of Valencia (UV), Spain.

Email: Jose.beltran@uv

Correspondência:

José Beltrán Llavador

Departamento de Sociología y Antropología Social, Universitat de València, Av. Tarongers, 4b, Valencia 46021, España

Data de submissão: Julho 2017

Data de avaliação: Outubro 2017

Data de publicação: Dezembro 2017 